AL IBTIDA: JURNAL PENDIDIKAN GURU MI (2021) Vol 8 (2) : 240-251

DOI: http://dx.doi.org/10.24235/al.ibtida.snj.v8i2.9040

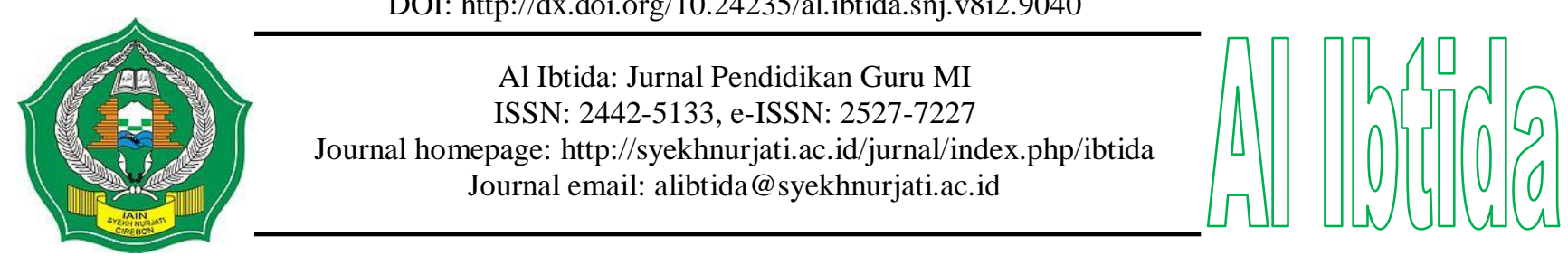

\title{
Journal-based Islamic Educational Management Teaching Materials Development for Madrasah Ibtidaiyah Teacher Education Students'
}

\author{
Imron Muttaqin* \\ *Madrasah Ibtidaiyah Teacher Education Study Program, Faculty of Tarbiyah and Teacher Training, \\ Institut Agama Islam Negeri Pontianak, Indonesia. \\ Email: imron.muttaqin@gmail.com \\ Rizki Susanto** \\ **Islamic Religion Education Study Program, Faculty of Tarbiyah and Teacher Training, \\ Institut Agama Islam Negeri Pontianak, Indonesia. \\ Email: rizkisusanto@iainptk.ac.id
}

Received: September 25 ${ }^{\text {th }}$ 2021. Accepted: October 18 ${ }^{\text {th }}$, 2021. Published: October $30^{\text {th }}, 2021$.

\begin{abstract}
This study aimed to develop the representative material of Islamic education management. The teaching materials using education management theories and thinking were enriched with articles using Mendeley reference management. Modified research and development designs method were used. Data were collected using a Google form. The population and sample were Madrasah Ibtidaiyah Teacher Education (PGMI) IAIN Pontianak students of the academic year 2020/2021. Findings reported that teaching materials developed from online journals have a high level of usefulness and are easy to use. The students can get the latest references published in online journals, making it easier to understand and learn about the course topic. This study suggests that lecturers and students use Mendeley to look for references and write scientific papers.
\end{abstract}

Keywords: Islamic education management, teaching material, scientific journal, mendeley.

\begin{abstract}
Abstrak
Penelitian ini bertujuan untuk mengembangkan materi representatif manajemen pendidikan Islam. Materi ajar yang menggunakan teori dan pemikiran manajemen pendidikan diperkaya dengan artikel dengan menggunakan referensi manajemen Mendeley. Metode penelitian dan pengembangan yang dimodifikasi digunakan. Pengumpulan data menggunakan google form, populasi dan sampel dari mahasiswa Pendidikan Guru Madrasah Ibtiadiyah (PGMI) IAIN Pontianak tahun ajaran 2020/2021. Hasil penelitian dilaporkan bahwa bahan ajar yang dikembangkan dari jurnal online memiliki tingkat kegunaan yang tinggi dan mudah digunakan. Mahasiswa dapat memperoleh referensi terbaru yang telah dipublikasikan di jurnal online, sehingga lebih mudah dipahami dan mudah dipelajari sesuai dengan topik mata kuliah. Penelitian ini menyarankan dosen dan mahasiswa menggunakan Mendeley untuk mencari referensi dan menulis karya ilmiah.
\end{abstract}

Kata kunci: manajemen pendidikan Islam, bahan ajar, jurnal ilmiah, mendeley. 
Imron Muttaqin, Rizki Susanto, Journal based Islamic Educational Management Teaching Materials...

\section{INTRODUCTION}

Teaching materials are systematically arranged learning materials used in the learning process (Pannen, 1995). Along with the development of science and technology, educators are no longer the only source of learning. Educators are the facilitators of the teaching and learning process while students become more active in learning. The students' activeness is shown by diligently reading the teaching materials that have been prepared. Good teaching materials make students more active and ready to receive course materials because they already have previous knowledge. According to Rowntree (1994), teaching materials are divided into 4 types including print-based teaching materials, technology-based teaching materials, teaching materials for practice or projects, and teaching materials for human interaction purposes. Meanwhile, Ellington and Race divide teaching materials into 7 types: print teaching materials, display teaching materials, audio teaching materials, audio teaching materials connected with silent visual materials, video teaching materials, and computer teaching materials (Race, 1997).

Studies exploring the journal-based education management teaching materials are still rarely done by researchers. A previous study investigated the development of teaching materials based on local wisdom (Ferdianto \& Setiyani, 2018); the result is a learning media module based on local wisdom. Hanifah, et al., (2019) investigated autoplay media based teaching materials. Findings of the study revealed that autoplay media based teaching materials were valid, effective, and practical in improving the students' understanding of mathematical concepts. Similar findings were also reported by Kharisma \& Asman (2018) who found that problem-based teaching materials in math subjects were practical and could be effectively used as teacher and student guides (Kharisma \& Asman, 2018). Other researchers tried to connect context with teaching materials; the results are also good because they can provide the students' learning experiences according to their environment and context (Perwitasari et al., 2018). On the different focus, Satriawan and Rosmiati (2017) developed contextual-based teaching materials combined with local wisdom to improve the students' understanding of the physics concepts. Husada et al. (2020) also developed visual storytelling teaching materials in thematic learning; the results were valid, practical, and effective. Other research used social media as preferred teaching materials for the $\mathrm{Z}$ generation (VizcayaMoreno et al., 2020). Khoiron et al. (2021) stated social as teaching material in emergency education. Meanwhile, Hendriana, et al. (2019) reported that her initial teaching materials involved covers, prefaces, table of contents, content section. 
It is shown above that studies investigating the teaching materials obtained from scientific journals have rarely been conducted. Therefore, this research is worth of empirical investigation. The teaching materials can also be used especially for education management courses. Teaching materials should meet the needs of students by estimating their feasibility and characteristics. The eligibility are determined from the four elements; (1) the feasibility of the content of the material, (2) the feasibility of presentation, (3) the feasibility of language, and (4) the feasibility of the characteristics of the teaching material seen from the five elements; (1) self-instructional, (2) self-contained, (3) stand-alone, (4) adaptive, and (5) userfriendly (Arsanti, 2018).

There are at least two reasons why online teaching materials are needed. First, it provides teaching materials easily accessible to learners. Second, learners get clear guidance in learning and exploring the field of science studied. The advancement of information and communication technology has offered solutions for the publication of scientific work through an open journal system (OJS). The term is used to refer to scientific journals electronically published using a system created by the Public Knowledge Project (PKP) for free. The official website of the OJS system has been reported used by more than 25,000 scientific journals around the world (pkp.sfu.ca/ojs/). The large community of open journal system users makes it fast and easy to develop knowledge. Scientific journals are the highest references recognized by academics. Therefore it deserves to be used as teaching materials for courses. Moreover, the scientific journals are published after getting the recommendation of reviewers appointed by the editor in chief. With this thinking, the use of scientific journals as a source of teaching materials becomes worthy of consideration by lecturers in universities and students.

The concept of educational management and topics discussed include the results of the latest study obtained on the website. This course is a integration of management and Islamic education. The science of management has grown rapidly and become a discipline in itself. Meanwhile, Islamic education has also grown rapidly after Muslim scholars began to realize the importance of integration and interconnection of all fields of Islamic teachings. Islamic education deals with the knowledge, choices, and actions taken by practitioners of Islamic education (Bagheri \& Khosravi, 2006). Islamic education must be based on Islamic teachings and modern years between them, while the choice taken depends on the learning material's purpose, methods, and characteristics. Although several scholars have different opinions about Islamic education, they also have similarities. They agree that the teachings of Islam are the basis of education and they use the Qur'an, Hadith, Ijma' and Qiyas as the source of the law. 
Conceptually, Islamic education has strong foundations so that it is possible to continue to progress and develop. The progress and development of Islamic education certainly require ongoing efforts from the managers of Islamic educational institutions to develop, improve, and innovate. In its development, Islamic education is influenced by the cultural identity of Islam (Abu-Rabi, 1989), so it has its own characteristics different to other education. In addition, Islamic education is also influenced by the local cultural identity where Islamic education is located. Islamic education is an education based on the teachings or guidance of Islam (Muwahid \& Soim, 2013), so that it has uniqueness, characteristics, and goals that require good management to achieve the educational goals set by each educational institution. Therefore, it requires good management and integrated Islamic teachings. The most common Islamic education institutions are universities, pesantren, and madrasas. Of these various forms, this study chose a location at the college, namely IAIN Pontianak, because the substance and purpose of this research can be directly applied. There are three reasons why this research is necessary: 1) students have difficulty in getting teaching materials, and 2) students does not only need teaching materials that are easy to get but also updated with the results of recent research, and 3) the need for digital teaching materials (Asrizal et al., 2017).

\section{METHODS}

Gall \& Borg research and development model was used to develop and validate this product (Gall \& R., 2003). These research steps include: reviewing the findings of product research to be developed, developing product based on these findings, conducting field trials following the background in which the product will be used, and revising the results of field tests (Setyosari, 2010). Research and Development are a research method that produce products to be validated by the appropriate experts and researchers. This study was used to find out and illustrate the usefulness and ease of teaching materials; this study also uses descriptive statistics to describe, procentage, and data centralize (Muchson \& MM, 2017). Likert scale included four options, (4) strongly agrees, (3) agree, (2) disagree and (1) strongly disagree. Using purposive sampling, this study involved the third semester students of PGMI FTIK IAIN Pontianak as a population. The sample criteria were agreed to participate in Mendeley reference management training, have their internet connection, and fill out statement items on Google Forms.

This research and development study used research and data collection stage. First, in planning and preparing the teaching materials, the research and data collection were used to find the potential and problems that existed in educational management teaching materials. The problem obtained at the beginning was that some references were not updated and had 
not been enriched with the results of recent research. The references were mostly from books. Therefore, as an alternative solution, we used journal articles updated using reference management and also a collection of abstract results of cutting-edge research. Forum Discussion Group (FGD) showed that the students had difficulty in getting a bibliography and writing it on a paper. The problem was that the educational management teaching materials had not been updated. The references were still widely used books and did not include the latest research results.

Second, the planning stage was aimed to develop teaching materials equipped with journal articles and their full identity. The identity of the article consisted of the author, year, title, journal name, the volume of the issue, and the page number. The identity was used to make it easier for students to write references or bibliographies. Article writing was made separately because it was an add-on to the students' insights and knowledge. Furthermore, research instruments were created to find out the students' perceptions of the benefits of using journal-based teaching materials. Each statement of assessment of the usefulness and ease of use of has 5 points. The statement item was made in Google form to facilitate researchers in testing validity, reliability and descriptively explaining the study results. The third stage is preparation of teaching materials. We prepared teaching materials about educational management from books, then equipped with journal articles with the complete identity and then conducted validity and reliability test. SPSS software was used in administering the correlation test.

\section{RESULTS AND DISCUSSION}

The problem identification stage used a forum discussion group to find references and teaching materials that had not been enriched with the latest research results. After discussions with the research team, it was agreed that to answer the student's problems, Mendeley reference manager was used. 10 valid and reliable statement items were used as measurement of usefulness and ease of use. The results of the validity and reliability tests are as follows.

Table 1. Validity test

\begin{tabular}{lcccc}
\hline No & Code & Correlation & Significance & Decision \\
\hline 1. & KF1 & 0,707 & 0,000 & Valid \\
2. & KF2 & 0,688 & 0,000 & Valid \\
3. & KF3 & 0,808 & 0,000 & Valid \\
4. & KF4 & 0,734 & 0,000 & Valid \\
5. & KF5 & 0,785 & 0,000 & Valid \\
6. & KM1 & 0,865 & 0,000 & Valid \\
7. & KM2 & 0,499 & 0,000 & Valid \\
8. & KM3 & 0,769 & 0,000 & Valid \\
\hline
\end{tabular}


Imron Muttaqin, Rizki Susanto, Journal based Islamic Educational Management Teaching Materials...

\begin{tabular}{lllll}
\hline 9. & KM4 & 0,727 & 0,000 & Valid \\
10. & KM5 & 0,760 & 0,000 & Valid \\
\hline
\end{tabular}

SPSS software was used to test item reliability. The reliability of item was determined by the Cronbach's alpha score. The test results are as follows;

Table 2. Reliability Statistics Test

\begin{tabular}{ccc}
\hline \multicolumn{3}{c}{ Reliability Statistics } \\
\hline $\begin{array}{c}\text { Cronbach's } \\
\text { Alpha }\end{array}$ & $\begin{array}{c}\text { Cronbach's Alpha Based } \\
\text { on Standardized Items }\end{array}$ & N of Items \\
\hline 0.774 & 0.926 & 42 \\
\hline
\end{tabular}

The Cronbach's Alpha score was 0.774. We decided that all the items used in this study were reliable because the score was above 0.7 . At the limited product trial stage, the trial was conducted on a small scale. This trial was conducted with a survey about the perception of third-semester students of PGMI about teaching materials. This perception survey was used to improve teaching materials to find out what the students needed. After testing the product and getting the input, the next step was to revise the product. At this stage, a re-analysis of the items was done to know some students that did not agree with the statement.

The researchers find out that there are some aspects needed to be enhanced in the teaching materials: a) It is necessary to highlights the important points (it is important because it will make it easier for students to learn and memorize the term because it is written prominently on teaching materials; b) In the article reference section of the journal, students have difficulty in accessing the essence and research results, so it needs to be revised by displaying the abstract of the article in question; c) In order to be easy to use, it is necessary to display article links so that it is easier when traced online.

In the early stages of the percentage results, most students concurred that the materials of this journal-based article were useful and easy. In contrast,the percentage of the item 1 (understanding and improving the ability to understand the restoration materials) was $40.5 \%$. It was not easy for students to understand lectures from the journal-based teaching materials. Especially at point 1 (a question about improving ability and understanding) and point 5 (a question about students' knowledge of the results of the latest research), there were technical problems regarding signals in the area because many students came from rural areas during the online study period. The laptops used also did not support Mendeley applications. The percentage of answers after improvements showed that the average student answered strongly and agreed with the statement.

At the product revision stage, additional materials from the article discuss educational management; Islamic education management verses (Hidayat \& Wijaya, 2017), Islamic 
education concept (Amiruddin, 2018; Khasanah, 2020; Muthoharoh, 2020; Syaban, 2019), Islamic education epistemological review (Rahman, 2012), Islamic education quality improvement strategy (Muwahid \& Soim, 2013), the integrative concept of Islamic education management (Chotimah, 2014), management of Islamic educational institutions (Yaqin, 2016), and educational institutions in Indonesia (Bafadhol, 2017).

After the product revision stage, the stage of the user trial involved 42 Madrasah Ibtidaiyah Teacher Education (PGMI) students. The results of SPSS are shown in the following table:

Table 3. Descriptive statistics

\begin{tabular}{lr|r|r|r|r|r}
\hline & N & \multicolumn{1}{c|}{ Minimum } & \multicolumn{1}{c}{ Maximum } & \multicolumn{1}{c}{ Sum } & Mean & $\begin{array}{c}\text { Std. } \\
\text { Deviation }\end{array}$ \\
\hline KF1 & 42 & 3 & 4 & 154 & 3.67 & .477 \\
\hline KF2 & 42 & 3 & 4 & 144 & 3.43 & .501 \\
\hline KF3 & 42 & 3 & 4 & 140 & 3.33 & .477 \\
\hline KF4 & 42 & 3 & 4 & 147 & 3.50 & .506 \\
\hline KF5 & 42 & 3 & 4 & 145 & 3.45 & .504 \\
\hline KM1 & 42 & 3 & 4 & 138 & 3.29 & .457 \\
\hline KM2 & 42 & 3 & 4 & 140 & 3.33 & .477 \\
\hline KM3 & 42 & 3 & 4 & 135 & 3.21 & .415 \\
\hline KM4 & 42 & 3 & 4 & 137 & 3.26 & .445 \\
\hline KM5 & 42 & 3 & 4 & 139 & 3.31 & .468 \\
\hline Valid N & 42 & & & & & \\
(listwise) & & & & & & \\
\hline
\end{tabular}

As shown in the table above, there were 42 students participated. For KF1 item (using journal-based teaching materials improved my ability to understand lecture materials) obtained a minimum score of 3 and a maximum value of 4 . The mean value was 3.67, and the standard deviation was 0.477 . Because the mean value is greater than the standard deviation value, it can be said that almost all students state that journal-based teaching materials improve their ability to understand lecture materials. KF2 (the use of teaching materials to facilitate learning online and offline) obtained a minimum score of 3 and a maximum of 4 , with a mean value of 3.43 and a standard deviation of 0.501 . It showed that the students agreed to the statement that the teaching materials allow them to learn more easily. Furthermore, the KF3 statement item (students quickly understand the materials) obtained a minimum score of 3 and maximum of 4, with a mean value of 3.33 and a standard deviation of 0.477 . Students agreed to the statement that the teaching materials make it easier for them to learn. In the next statement, KF4 (students can learn from 
the latest research results), a minimum score was 3 and a maximum was 4 , with the mean value of 3.50 and the standard deviation of 0.506. Lastly, for KF5 item that states that journal-based teaching materials help students' lectures, the mean value was 3.45 and the standard deviation was 0.504 . Because the mean is greater than the standard deviation value, it can be said that the students have almost the same answer.

The perspective of the ease of teaching materials based on KM1 (I am helped to understand the material by using teaching materials based on scientific journals) obtained a minimum value of 3 and a maximum of 4 , with the mean value of 3.29. The standard deviation was 0.457 . KM2 obtained a minimum value of 3 and a maximum of 4 . The mean value was 3.33 and the standard deviation was 0.477. KM3 (materials and pages are quite easy to remember) obtained a minimum value of 3 and a maximum of 4 . The mean value was 3.21 and the standard deviation was 0.415 . KM4 (this scientific journal-based teaching material is easy to learn) obtained a minimum value of 3 and a maximum of 4 , with a mean value of 3.26 and a standard deviation of 0.445 .

Perspective on the last ease of KM5 (journal-based teaching materials are easy to use) obtained a minimum value of 3 and a maximum of 4 , with the mean value of 3.31 and the standard deviation of 0.468 . All results showed that a mean value was greater than the standard deviation, meaning that the students' answers were identical. The data analysis show that the journal-based teaching materials provide high benefits and convenience. Changes to the design and appearance of teaching materials, in addition to using highlight, are also enriched by the Mendeley application. It facilitates students in the search and writing of articles. The last stage is Limited Products. Research products in the form of journal-based educational management teaching materials were produced limitedly for use in educational management courses.

The results of the study show that the journal-based teaching materials developed are suitable for use in learning. Teaching materials are developed by enriching the sources or reading materials of journal articles using Mendeley. This reference management is recognized to improve social networks to improve the educational process (Zaugg et al., 2011). Mendeley is also recognized for accelerating the transfer of science appropriating to the field of science and scientific specialization (Mohammadi \& Thelwall, 2014), and help student to write reference accuracy (Patak \& Innovation, 2019). Among the benefits of using Mendeley is that this software could avoid plagiarism done by students because of their instant habits of wanting to complete college assignments quickly; the use of journal-based teaching materials using Mendeley also has an impact on the writing of student scientific works (Salija et al., 2016). The findings of this study are in accordance with the Demirkan's opinion on learning through 
digital media (Demirkan \& Research, 2019), also strengthening the results of Marpaung's research on ICT-based teaching materials (Marpaung \& Syahputra, 2018).

Mendeley can also be used to help academic writing (Patak \& Tahir, 2019). It can significantly improve the accuracy of citations (Iskandar \& Patak, 2019) and improve student literacy (Hudriati et al., 2018). It can also help identify themes and avoid plagiarism (Salija et al., 2016) for students, even help write dissertations (Kousha \& Thelwall, 2019). The benefit of this journal-based teaching materials are: a) Teaching materials developed provides new insights and knowledge related to materials based on scientific journal-based research results; b) Teaching materials make it easier for students to understand and combine the materials with the latest findings to keep their knowledge updated; c) Students easily write and imitate scientific works that have been published in scientific journals both in Indonesian and English.

This study weaknesses are: 1) The dependence of the internet (especially when searching for articles in scientific journals) and 2) the large bandwidth of the internet connection so that, during the covid-19 pandemic, it is difficult for students who are in areas with a lack of access to the internet. The development of journal-based teaching materials is still relatively new, so the researchers hope that there will be other findings of further research focusing on education management to add the latest information about the theory and application of the educational management field.

\section{CONCLUSION}

This study reveals that Islamic education management teaching materials based on journals are useful. The teaching materials that contain article titles, abstracts, and keywords are valuable for students, helping them to understand the findings and suggestions of the latest research to accelerate the mastery of educational management materials. Findings of this research provide new insights on the development of teaching materials. The research results can be implemented in other courses because it is easier to obtain references using reference management tools. The journal-based teaching materials make it easier for lecturers and students to know the state of the art and novelty because it can filter articles based on the year of publication. By adding insights into journal-based teaching materials, this study enriches previous findings on local wisdom, contextual-based, storytelling, and HOTS. For other researchers, it is advisable to continue this research in other courses or take different themes related to scientific journals for teaching materials. 


\section{REFERENCES}

Abu-Rabi, I. M. (1989). Modern trends in islamic education. Religious Education, 84(2), 186200. https://doi.org/10.1080/0034408890840204

Amiruddin, M. F. (2018). Konsep Pendidikan Islam Menurut KH. Hasyim Asy'ari. Dirasah: Jurnal Studi Ilmu dan Manajemen Pendidikan Islam, 1(1), 17-31. http://ejournal.iaifa.ac.id/index.php/dirasah/article/view/24

Annisa, S. L. (2018). Pengembangan Bahan Ajar berbasis HOTS untuk Meningkatkan Kemampuan Pemecahan Masalah Matematis Mahasiswa. Kreano: Jurnal Matematika Kreatif-Inovatif, 9(2), 191-197. https://doi.org/10.15294/kreano.v9i2.16341

Arsanti, M. (2018). Pengembangan Bahan Ajar Mata Kuliah Penulisan Kreatif Bermuatan Nilai-Nilai Pendidikan Karakter Religius Bagi Mahasiswa Prodi Pbsi, Fkip, Unissula. https://jurnal.umk.ac.id/index.php/kredo/article/view/2107

Asrizal, A., Festiyed, F., \& Sumarmin, R. (2017). Analisis Kebutuhan Pengembangan Bahan Ajar Ipa Terpadu Bermuatan Literasi Era Digital Untuk Pembelajaran Siswa Smp Kelas Viii. Jurnal Eksakta Pendidikan (Jep), 1(1), 1-1. https://doi.org/10.24036/jep/vol1iss $1 / 27$

Bafadhol, I. (2017). Lembaga Pendidikan Islam di Indonesia. Edukasi Islami: Jurnal Pendidikan Islam, 6(11), 14.

Bagheri, K., \& Khosravi, Z. (2006). The Islamic Concept of Education Reconsidered. American Journal of Islamic Social Sciences, 23(4), 88-103. https://doi.org/10.35632/ajiss.v23i4.448

Cahyadi, R. A. H. (2019). Pengembangan Bahan Ajar Berbasis Addie Model. Halaqa: Islamic Education Journal, 3(1), 35-35. https://doi.org/10.21070/halaqa.v3i1.2124

Chotimah, C. (2014). Komplemen Manajemen Pendidikan Islam: Konsep Integratif Pelengkap Manajemen Pendidikan Islam. Jurnal Teras, 1. http://repo.iaintulungagung.ac.id/id/eprint/15066

Demirkan, O. J. E. P. A., \& Research, S. (2019). Pre-Service Teachers' Views about Digital Teaching Materials. 14(1), 40-60.

Ferdianto, F., \& Setiyani, S. (2018). Pengembangan Bahan Ajar Media Pembelajaran Berbasis Kearifan Lokal Mahasiswa Pendidikan Matematika. JNPM (Jurnal Nasional Pendidikan Matematika), 2(1), 37-37. https://doi.org/10.33603/jnpm.v2i1.781

Gall, M. D. G. J. P. B., \& R., W. (2003). Educational Research An Introduction (Vol. Seventh Edition). Pearson Education Inc.

Hanifah, N. H., Arifuddin, A., Walid, M., Padil, M., Bashith, A., \& Busro, B. (2019, March). Developing autoplay media based mathematics teaching materials for elementary school. In Journal of Physics: Conference Series (Vol. 1175, No. 1, p. 012265). IOP Publishing.

Hendriana, H., Putra, H. D., Hidayat, W. J. E. J. o. M., Science, \& Education, T. (2019). How to design teaching materials to improve the ability of mathematical reflective thinking of senior high school students in Indonesia? , 15(12), em1790.

Hidayat, R., \& Wijaya, C. (2017). AYAT - AYAT ALQURAN Tentang Manajemen Pendidikan Islam. Lembaga Peduli Pengembangan Pendidikan Indonesia, 1, 308-308. http://repository.uinsu.ac.id/2835/1/Ayat Al Quran TTg Manajemen.pdf 
Hudriati, A., Rusdiah, Patak, A. A., \& Basri, M. (2018). Assessing Indonesian University Students' preferences on Mendeley reference manager for scientific writing. International Journal on Advanced Science, Engineering and Information Technology, 8(5), 2211-2218. https://doi.org/10.18517/ijaseit.8.5.6671

Husada, S. P., Taufina, T., \& Zikri, A. (2020). Pengembangan Bahan Ajar Pembelajaran Tematik dengan Menggunakan Metode Visual Storytelling di Sekolah Dasar. Jurnal Basicedu, 4(2), 419-425. https://doi.org/10.31004/basicedu.v4i2.373

Iskandar, \& Patak, A. A. (2019). The significance of Mendeley usage on the accuracy of citation and references. International Journal of Humanities and Innovation (IJHI), 2(4), 108-114. https://doi.org/10.33750/ijhi.v2i4.51

Kharisma, J. Y., \& Asman, A. (2018). Pengembangan Bahan Ajar Matematika Berbasis Masalah Berorientasi pada Kemampuan Pemecahan Masalah Matematis dan Prestasi Belajar Matematika. Indonesian Journal of Mathematics Education, 1(1), 34-34. https://doi.org/10.31002/ijome.v1i1.926

Khasanah, L. (2020). KONSEP PEMIKIRAN PENDIDIKAN ISLAM MENURUT KH. HASYIM ASY'ARI. QALAM: Jurnal Pendidikan Islam, 1(2).

Khoiron, M., Harmanto, H., Kasdi, A., \& Wardani, A. R. J. T. I. J. o. S. S. (2021). Development of Digital Social Studies Teaching Materials in The Era of Pandemic Emergency Learning. 4(1).

Kousha, K., \& Thelwall, M. (2019). Can Google Scholar and Mendeley help to assess the scholarly impacts of dissertations? Journal of Informetrics, 13(2), 467-484. https://doi.org/10.1016/j.joi.2019.02.009

Marpaung, T., \& Syahputra, M. J. A. T. J. P. K. M. (2018). Making Learning Teaching Materials in School Based On Information And Communication Technology. 3(2), 202206.

Mohammadi, E., \& Thelwall, M. (2014). Mendeley readership altmetrics for the social sciences and humanities: Research evaluation and knowledge flows. Journal of the Association for Information Science and Technology, 65(8), 1627-1638. https://doi.org/10.1002/asi.23071

Muchson, M., \& MM, S. (2017). Statistik Deskriptif. Spasi Media.

Muthoharoh, M. (2020). Pemikiran Pendidikan Islam Perspektif KH. Hasyim Asy'ari. TABYIN: JURNAL PENDIDIKAN ISLAM, 2(2), 32-39. http://e-journal.staiiu.ac.id/index.php/tabyin/article/view/91

Muwahid, S., \& Soim. (2013). Manajemen Pendidikan Islam, Strategi Dasar Menuju Peningkatan Mutu Pendidikan Islam. 101-101. http://repo.iaintulungagung.ac.id/4158/1/BUKU MANAJEMEN PENDIDIKAN ISLAM.pdf

Pannen. (1995). Mengajar di Perguruan Tinggi. PAU-PPAI, Universitas Terbuka.

Patak, A. A., \& Tahir, M. (2019). Avoiding plagiarism using mendeley in Indonesian higher education setting. International Journal of Evaluation and Research in Education, 8(4), 686-692. https://doi.org/10.11591/ijere.v8i4.20268

Patak, A. A. J. I. J. o. H., \& Innovation. (2019). The significance of Mendeley usage on the accuracy of citation and references. 2(4), 108-114.

Perwitasari, S., Wahjoedi, \& Sa'dun, A. (2018). Pengembangan Bahan Ajar Tematik Berbasis Kontekstual. Jurnal Pendidikan: Teori, Penelitian, dan Pengembangan, 3(3), 278-285. http://journal.um.ac.id/index.php/jptpp/article/view/10623 
pkp.sfu.ca/ojs/. Open Journal Systems. Retrieved 5 November 2021 from https://pkp.sfu.ca/ojs/ Race, E. (1997). Producing teaching materials. Kogan Page.

Rahman, A. (2012). Pendidikan Agama Islam dan Pendidikan Islam-Tinjauan Epistemologi dan Isi-Materi. Jurnal Eksis, 8(1), 2053-2059.

Rowntree, D. (1994). Preparing Material for Open, Distance and Flexible Learning. Kogan Page Limited.

Salija, K., Hidayat, R., \& Patak, A. A. (2016). Mendeley impact on scientific writing: Thematic analysis. International Journal on Advanced Science, Engineering and Information Technology, 6(5), 657-662. https://doi.org/10.18517/ijaseit.6.5.1140

Satriawan, M., \& Rosmiati, R. (2017). Pengembangan Bahan Ajar Fisika Berbasis Kontekstual Dengan Mengintegrasikan Kearifan Lokal Untuk Meningkatkan Pemahaman Konsep Fisika Pada Mahasiswa. JPPS (Jurnal Penelitian Pendidikan Sains), 6(1), 1212-1212. https://doi.org/10.26740/jpps.v6n1.p1212-1217

Setyosari, P. (2010). Metode Penelitian Pendidikan dan Pengembangan. Kencana, 194-195.

Syaban, M. (2019). Konsep Dasar Manajemen Pendidikan Islam. Al-Wardah, 12(2), 131-131. https://doi.org/10.46339/al-wardah.v12i2.141

Vizcaya-Moreno, M. F., Pérez-Cañaveras, R. M. J. I. J. o. E. R., \& Health, P. (2020). Social media used and teaching methods preferred by generation $\mathrm{z}$ students in the nursing clinical learning environment: A cross-sectional research study. 17(21), 8267.

Yaqin, N. (2016). Manajemen Lembaga Pendidikan Islam. Madinah: Jurnal Studi Islam, 3(2), 93-105-193 - 105. http://ejournal.iai-tabah.ac.id/index.php/madinah/article/view/178

Zaugg, H., West, R. E., Tateishi, I., \& Randall, D. L. (2011). Mendeley: Creating communities of scholarly inquiry through research collaboration. TechTrends, 55(1), 32-36. https://doi.org/10.1007/s11528-011-0467-y 